\title{
OBSCENITY IN MODERN ENGLISH LAW
}

\author{
J. E. Hall Williams*
}

Members of the jury, the charge against the accused is one of publishing what is called an obscene libel.... The verdict that you will give is a matter of the utmost consequence, not only to the accused but also to the community in general. It is of great importance in relation to the future of the novel in the civilized world. ... Your verdict will have a great bearing upon where the line is drawn between liberty and that freedom to read and think as the spirit moves us, on the one hand, and, on the other, a licence that is an affront to the society of which each of us is a member. The discharge of this important duty rests fairly and squarely on your shoulders.

It was with these striking words that Stable, J., began his remarkable direction to the jury in the case of Regina v. Martin Secker \& Warburg, Ltd. at the Central Criminal Court in London on July 2, I954. ${ }^{1}$ The wise guidance contained in the rest of the summing up and the jury's subsequent acquittal of this reputable firm of publishers did much to allay the fears of those who were anxious about the trend of recent obscenity prosecutions. There had been a fresh wave of such cases, quite as disturbing as anything which occurred in the r920's and I930's, and the Warburg case was a welcome sign that all was not lost, even in the courts, in the cause of literary freedom.

But before describing the present state of the controversy over the treatment of obscene publications in English law, it may be as well to endeavor to state the existing law; then the test of obscenity laid down in the Hicklin case ${ }^{2}$ will be considered in detail; an account will be given of the procedure under the Obscene Publications Act, $18577^{3}$ and finally, the recent developments will be discussed, including the proposals for reform, culminating in the Obscene Publications Bill of March I5, 1955.

\section{I}

\section{The Existing Law Relating to Obscene Publications}

\section{A. The Misdemeanor of Publishing an Obscene Libel}

Originally, the jurisdiction to deal with obscene publications was confined to the ecclesiastical courts, and the Common Law courts were chary of interfering. But in

*LL.B. 1942, LL.M. 1953, University of Wales; of the Middle Temple, Barrister-at-Law, 1949. Lecturer in Law, London School of Economics and Political Science. Member of the Scientific Committce, Institute for the Study and Treatment of Delinquency. Contributor to legal and other publications. Visiting Associate Professor of Law, New York University School of Law, October 1955-March I956.

1 [1954] I Weckly L. R. I138.

20 \& 2 I VICT., c. 83.

${ }^{2}$ L.R. 3 Q.B. 360 ( 1868 ).

* Bill 56 (March 15, 1955).

"See Regina v. Read, Fort. 98, 92 Eng. Rep. 777 (K.B. 1708). The defendant having been convicted, a motion in arrest of judgment succeded on the ground that the offense was "proper for ecclesiastical conusance, and no offence at common law." 
I727, in the case of Rex $v$. Curl, ${ }^{6}$ after some hesitation, the publication of the book called Venus in the Cloister, or The Nun in Her Smock was held to be punishable as an offense at common law, and that decision is the origin of the present common law misdemeanor of publishing an obscene libel. This is punishable with a fine or imprisonment or both, and there appears to be no limit to the amount of the fine or the term of imprisonment, though in practice, a term of more than two years would probably be regarded as exceptional. ${ }^{7}$

It has been held that procuring obscene prints for the purpose of sale or dissemination is an offense, but not simply being in possession of such prints with that intent, ${ }^{8}$ though such prints (and even the negatives from which prints can be made) ${ }^{9}$ may be the subject of seizure and destruction under the Obscene Publications Act, 1857. A person may be guilty of the misdemeanor even though all he does is to insert in a paper of which he is the editor advertisements which he knows relate to the sale of obscene books. ${ }^{10}$

The misdemeanor of publishing an obscene libel involves two elements, (I) the publication and (2) the obscene libel, both of which will now be briefly considered:

The Publication: It is sufficient for this purpose that the obscene libel is shown to another person or sent to him. The test for publication appears to be no more stringent than for the purpose of a civil action for libel. In Rex $v$. De Montalk, ${ }^{11}$ the only person to whom the accused had published the mansucript was Mr. de Lozey, the managing director of a firm which produced and set up type. The accused had requested him to set the manuscript up in type for printing elsewhere, and after he had left, Mr. de Lozey informed the police, as a result of which the accused was prosecuted and convicted. His appeal was dimissed.

The Obscene Libel: There must be some writing, print, drawing, or photograph. Mere words are not enough; a libel is required-i.e., something in a more or less permanent form. ${ }^{12}$ The question whether a gramophone record or a recording of a broadcast could amount to an obscene libel has not yet been tested, as far as the writer is aware; and it is doubtful whether a direct broadcast by radio or television would be included, although, by analogy with developments in the civil law of

\footnotetext{
${ }^{\circ}$ Str. 788, 93 Eng. Rep. 849 (K.B. 1727). The defendant having been convicted, a motion in arrest of judgment on the same grounds as in Regina $v$. Read, stupra note 5, was favored by Fortescue, J., but not by the other judges. In the following term, when Page, J., had taken the place of Fortescue, J., it was held unanimously that this was a temporal offense.

${ }^{7}$ In Rex v. Morris, [195I] I K.B. 394, Lord Goddard, C.J., cxplained that a court can imprison for common law misdemeanor for any term, at its discretion, provided that the sentence is not inordinate. Sec also Rex v. Bryan, (I95I) 35 Crim. App. R. 12I; and Rex v. Higgins, [1952] I K.B. 7.

${ }^{8}$ Dugdale v. Regina, I El. \& Bl. 435, I 8 Eng. Rep. 499 (K.B. I 853 ).

${ }^{\circ}$ Cox v. Stinton, [1951] 2 K.B, 1021.

${ }^{10}$ Rex v. De Marny, [1907] I K.B. 388, Lord Alverstone, C. J., at 39x, 392. This was a case under the Post Office (Protection) Act, I884, $47 \& 48$ Vict., c. $76, \$ 4$. Sec now Post Office Act, I953, 1 \& 2 ELIz. 2, c. 36, \$1I.

11 (1932) 23 Crim. App. R. 182. Sce also Regina v. Carlile, (1845) I Crim. L. Rcp. (Cox) 229.

12 J. F. Archbold, Pleading, Evidence \& Practice in Criminal Cases 1323 (33d ed., Butler \& Garsia 1954).
} 
libel, ${ }^{13}$ such media of communication ought now to be regarded as within the ambit of the law of obscene libel.

The libel must be obscene. The test of obscenity is contained in the judgment of Cockburn, C.J. in Regina v. Hicklin, which has been followed by the English courts ever since 1868 , and which has recently been expressly re-affirmed by Lord Goddard in Regina v. Reiter ${ }^{14}$ and applied by Stable, J., in the Warburg case. The words used by Cockburn, C. J., were:15

... The test of obscenity is this, whether the tendency of the matter charged as obscenity is to deprave and corrupt those whose minds are open to such immoral influences, and into whose hands a publication of this sort may fall.

It should be noted that a person accused of the common law misdemeanor of publishing an obscene libel may be tried by jury on indictment at Assizes or Quarter Sessions, but if it is thought expedient and the accused consents, the offenses can be tried summarily by the magistrates. ${ }^{16}$ During 1953 , the number of prosecutions was 38 , of which 33 were dealt with summarily and 5 were tried on indictment. These $3^{8}$ prosecutions led to 12 prison sentences and to fines and costs totalling $£ 3,300 .{ }^{17}$

\section{B. The Obscene Publications Act, 1857}

This preventive law was introduced by Lord Campbell shortly after Parliament had been dealing with a bill to restrict the sale of poisons and at a time when there had been some trials for obscene libel. ${ }^{18}$ His Lordship turned his mind to what he described as "a sale of poison more deadly than prussic acid, strychnine or arsenic," ${ }^{19}$ namely, the traffic in obscene publications which had grown up in and around Holywell Street, London.

Section I of the Act of 1857 empowers magistrates, before whom a complaint is made on oath to the effect

... that the complainant has reason to believe, and does believe, that any obscene books ... pictures, drawings, or other representations are kept in any ... shop, room, or other place ... for the purpose of sale or distribution ... lending upon hire, or being otherwise published for purposes of gain...

to give authority, by special warrant, to the police to enter the place and search for and seize the offending books or other articles. The complainant must first state upon oath that one or more of the articles in question "have been sold, distributed, ... lent, or otherwise published," and the magistrates must be satisfied that the

${ }^{13}$ See the Defamation Act, 1952, 15 \& 16 Geo. 6 \& I ELIz. 2, c. 66, \$1, which enacts that "For the purposes of the law of libel and slander, the broadcasting of words by means of wireless telegraphy shall be treated as publication in permanent form." This must be read in conjunction with $\S 16$ which defines "words" as including "pictures, visual images, gestures, and other methods of signifying meaning."

${ }^{14}$ [1954] 2 Wcekly L. R. $638 . \quad{ }^{15}$ L.R. 3 Q.B. 360,371 (1868).

18 'The Magistrates' Courts Act, 1952, 15 \& 16 Geo. 6 \& I Ez1z. 2, c. 55, \$\$18-21 and schedule I.

${ }^{17}$ Figures given by Mr. F. J. Odgers in the second of two broadcast talks, subsequently published as The Law and Obscenity, 52 THE LISTENER 613 (1954).

${ }^{18}$ See Alec Craig, The Banved Books of Englaxd 22 (1937). Another book on the subject, published in England, is George Ryley Scott, Into Whose Hands (1945).

${ }^{10}$ Cratg, op. cit. supra note 18 , at 22 . 
articles complained of are "of such character and description that the publication of them would be a misdemeanour, and proper to be prosecuted as such."

The next stage is that the articles seized must be taken before the justices, who must thereupon issue a summons calling upon the occupier of the house or other place which has been entered to appear within seven days before any two justices in petty sessions for the district to show cause why the articles seized should not be destroyed. In default of appearance of the person in question, or if he does appear and the magistrate shall, nevertheless, be satisfied that any of the articles are of the character stated in the warrant, the magistrates are required to order the articles to be destroyed, after allowing sufficient time for the lodging of any appeal.

\section{Other Relevant Legislation}

Both the postal authorities and customs officials have certain statutory powers in relation to articles in the post or imported into the United Kingdom. Under Section II of the Post Office Act, $1953,{ }^{20}$ which replaces earlier legislation, ${ }^{21}$ it is an offense $^{22}$

... to send or attempt to send or procure to be sent a postal packet which ... (b) encloses any indecent or obscene print, painting, photograph, ... film, book, card or written communication, or any indecent or obscene article whether similar to the above or not; or (c) has on the packet, or on the cover thereof, any words, marks or designs which are grossly offensive or of an indecent or obscene character.

Under the Customs and Excise Act, $1952,{ }^{23}$ which consolidates with amendments the enactments relating to customs and excise, there are powers to forbid the import of certain goods; and if prohibited goods are imported, they may be seized. They are then subject to forfeiture, subject to the provisions contained in schedule 7 of the act, which require notice to be given to any person who is believed to be the owner of the goods and confer upon such person the right to make a claim. Such a claim is to be adjudicated by a court, which, in practice, means a magistrates' court, and there is a right of appeal to Quarter Sessions and, by way of case stated, to the High Court. Goods, the importation of which is prohibited, include "indecent or obscene prints, paintings, photographs, books, cards, lithographic or other engravings, or any other indecent or obscene articles."

There are also various other powers to deal with obscenity under the Vagrancy Acts, $1824^{24}$ and $1838 ;^{25}$ the Metropolitan Police Act, $1839 ;^{26}$ the Town Police Clauses Act, $1847 ;^{27}$ the Indecent Advertisements Act, $1889 ;^{28}$ the Venereal Disease Act, I9I $7 ;^{29}$ and the Judicial Proceedings (Regulation of Reports) Act, $1926 .^{30}$

${ }^{20}$ I \& 2 Ex.1z. 2, c. 36.

21 The Post Office Act, r908, 8 Edw. 7 , c. $48, \$ 63$ (as amended by the Post Office (Amendment) Act, 1935, 25 Gro. 5, c. 15).

${ }^{22}$ Punishable, on summary conviction, with a fine not exceeding $\oint_{0} 10$ or, on conviction on indictment, with imprisonment for a term not exceeding twelve months. ( $(x I(2))$

${ }^{23} 15$ \& 16 GEO. 6 \& I ELIz. 2, c. 44 .

245 Geo. 4 , c. 83 .

27 IO \& II VICT., c. 89. $\quad{ }^{28} 52$ \& 53 VICT., c. 18.

${ }^{26} 2 \& 3$ VICT., c. 47.

I 6 \& 17 Geo. 5, c. 6I. For a more cxtended examination of the foregoing powers, see Stevas, Obscenity and the Law, [1954] Cris. L. Rev. 817, 821. 
II

\section{The Operatron of the Hicklin Test}

\section{A. Intention}

The so-called Hicklin test has been widely criticized for failing to make the intention of the accused to corrupt public morals the paramount requirement in connection with proof of an obscene publication. It is said that in adopting the test of the tendency of the matter to deprave and corrupt those whose minds are open to immoral influences and into whose hands a publication of this sort may fall, Cockburn, C. J., has undermined the protection which the doctrine of mens rea is designed to secure to the person accused of crime, with the result that such a person may be convicted of the misdemeanor on the basis of something which may have been far removed from his contemplation at the time of the publication-i.e., the tendency or likely effect of the work. ${ }^{31}$

Before considering the validity of these objections, it may be well to remember that the essence of the decision in the Hicklin case was that however praiseworthy the motive of the accused may have been, that was no defense. The motive which prompts a person to commit a crime is, generally speaking, disregarded in criminal law, although it may be relevant as evidence from which a conclusion may be drawn as to the accused's responsibility for the deed (as circumstantial evidence), and it may be urged in mitigation of sentence. The actual decision in the Hicklin case turned on this point and nothing else. However, the test of obscenity adopted by Cockburn, C. J., has been sanctified by long usage, and it is to an examination of this and the reasoning underlying the judgments of Cockburn, C. J., and his fellow judges that we must now turn.

It is submitted that the real weakness of all the judgments lies in the fact that they treat the presumption that the accused must be deemed to have intended the consequences of his act as irrebuttable, whereas it would have been more correct to treat this presumption as one which yields in the face of strong evidence. ${ }^{32}$ In Steele v. Brannan, ${ }^{33}$ Grove, J., declined to follow this line of reasoning and emphatically rejected the view "that the intention which really actuated a person is always to be conclusively deduced from the character of the act itself." The learned judge expressed the opinion that ${ }^{34}$

when, from the act committed, an immediate intention ${ }^{35}$ of a particular character would

${ }^{31}$ For recent criticism of the Hicklin test along these lines, see Stevas, supra note 30, and Intent and the Law, 48 New Statesman and Nation 428 (1954). Sec also the spceches of Mr. Roy Jenkins, M.P., 533 H. C. Deb. (5th ser.) I015 (1954); 537 H. C. Deb. (5th ser.) I091 (1955); and 538 H. C. DEB. (5th ser.) Ir33 (1955).

${ }^{32}$ See Glanville L. Williams, Criminal Law-The General. Part \$27, at 77 et seg. (1953).

${ }^{33}$ L.R. 7 C.P. $26 \mathrm{I}, 27 \mathrm{I}$ ( 1872 ). ${ }^{34}$ Ibid.

${ }^{35}$ The recorder in the Hicklin case used this phrase to describe the motive of the distributor of the pamphlets. Cockburn, C. J., preferred to use the phrase "ulterior object." Glanville Williams speaks of motive as "ulterior intention." Criticism of Cockburn, C. J., for using confusing language cannot be supported, for he was simply following the terminology of the recorder in the court below, and, in each case, put his own paraphrase alongside. 
be implied, the party doing the act is not exempted by reason of some other paramount intention of a different description, which actually operated upon his mind. The only question, therefore, would appear to be, what is the intention which may fairly be implied from the act of offering for indiscriminate sale a work dealing with subjects of a filthy nature.

It is hardly surprising that the Hicklin court took this view of the presumption, for during the nineteenth century, and, indeed, until quite recently, it was regarded as an inflexible rule of law. It was not until $x 95^{\circ}$ that this misconception was finally cleared up with the statement by Denning, L. J., to the effect that "there is no 'must' about it; it is only 'may.' The presumption of intention is not a proposition of law but a proposition of ordinary good sense." 36 The importance attached to this presumption in the nineteenth century may partly be accounted for by the fact that until $1898,{ }^{37}$ in trials of felony, the accused was not allowed to give evidence and, consequently, was not available for cross-examination, so that if his intention in committing the deed remained obscure, it could only be presumed from his conduct, as no questions could be put to him concerning his state of mind.

At the present-day, criminal liability is regarded as depending on a subjective criterion, which may be described as the presence of either intention or recklessness on the part of the accused. Applying this criterion to the Hicklin case, it may be said that the accused was guilty either if he intended to corrupt the public morals or, if he was merely reckless, if this would be the result of indiscriminate sale of the pamphlets. Recklessness, as a state of mind, involves an objective element, as Professor Glanville Williams has observed. ${ }^{38}$ Not only must there be advertence to the risk of producing the prohibited harm, but it must be clear that no reasonable person would have proceeded with this conduct in view of the attending risk. This surely is where the test of the tendency to deprave and corrupt comes in. The court must decide whether it was reasonable for the accused to have acted as he did. If no reasonable person would have published the matter because of the risk, then we reach the conclusion that the accused is to be condemned because he was reckless as to the consequences-that is, the tendency of the matter published to deprave and corrupt. On this view, there is nothing wrong with the Hicklin test, save that it fails to express clearly enough the principles upon which it is based. It does not exclude intent in the sense of mens rea, and any reform which aimed only at introducing a requirement of intention and left out of account recklessness would fall short of the mark, as the draftsmen of the Obscene Publications Bill, 1955, seem to have realized.

It has been said that support for restoring the requirement of intention can be found in the law relating to seditious libel and blasphemy, and reference is made to the change introduced by Fox's Libel Act, $1792,{ }^{39}$ which made it clear that the

\footnotetext{
${ }^{30}$ Hosegood v. Hosegood, I T.L.R. 735 (1950).

${ }^{37}$ Criminal Evidence Act, $1898,61 \& 62$ VICT., c. 36.

${ }^{38}$ See Williams, op. cit. supra note $32, \$ 20$, at 51 et seq.

39 32 Geo. 3, c. 6 o.
} 
jury was entitled to bring in a verdict on the general issue and not simply on the question of publication. It has been argued that ${ }^{40}$

... the effect of the Act on seditious libel was to require an illegal intention on the part of the publisher. The Act does not say so in so many words, but this is the effect of leaving the whole matter in issue to the jury.

It is submitted, with respect, that Fox's Libel Act does not have the effect here contended. The questions which are left to the jury under the general issue are not whether the accused published, and if so, did he intend to libel, but whether he published, and if so, was what he published calculated to expose some other person to public hatred, contempt, or ridicule or to damage him in his trade or calling? In other words, was the tendency of the publication to libel the person referred to? If so, then it is fair to presume that this was the intention of the publisher, or a least that he was guilty of recklessness.

Enough has been said to indicate that there is perhaps more validity in the Hicklin test than meets the eye, but that its meaning could be made plainer so that it might be better understood.

\section{B. Isolated Passages versus the General Character of the Work}

Several cases support the view that if any part of a publication is obscene, then the whole may be condemned. The Hicklin case and Steele v. Brannan were both cases where only part of the publication in question was obscene. In a case in $195^{2,41}$ where the offending part of a publication called Slick Bedtime Stories was held to be the illustrated cover, the Divisional Court upheld the decision of the magistrate ordering the destruction of the books and rejected the argument that only the cover should be destroyed. In the words of Lord Goddard, C.J., ${ }^{42}$

It is not necessary to show that a publication is obscene on every page. A publication may be obscene because part of it is obscene. Very few publications can be said to be obscene on every page. ...

This is such an obvious conclusion that it is somewhat surprising to find objection taken on the ground that the proper test is not "isolated passages," but the dominant effect of the work as a whole. ${ }^{43}$ It must be conceded that in the hands of an illiberal court, the "isolated passages" approach might lead to some strange results; but there is nothing to prevent English courts having regard to the general character of the work in question, and it is submitted that they do nowadays look at the obscenity objected to in its context or setting in the whole work. For example, Stable, J., in the Warburg case, told the jury ${ }^{44}$

... to consider whether the author was pursuing an honest purpose and an honest thread

'0 Stevas, supra note 30 , at 825 .

11 Paget Publications, Ltd. v. Watson, [1952] I All E.R. 1256.

12 Id. at 1257 .

${ }^{43}$ Stevas, stipra note 30 , at 828 . He says judicial authority is noncommittal.

" [1954] I Weekly L.R. Ir38, II43. 
of thought, or whether that was all just a bit of camouflage to render the crudity, the sex of the book, sufficiently wrapped up to pass the critical standard of the Director of Public Prosecutions.

Clearly, the work must be regarded as a whole; but at the same time, it must be realized that isolated passages may be of such a character as to infect the whole work with the character of an obscene publication.

There is a procedural point not unrelated to this which has arisen in the pasti.e., whether the indictment should specify the particular passages to which objection is taken, and if it is the whole work which is objected to, whether this should be reproduced in full. The Court of Appeal, in Regina $v$. Bradlaugh, ${ }^{45}$ held that the indictment should set out the words relied on by the prosecution as proving their case even if this involves reproducing the whole book. This is not the present law, nor is it usual to indicate or mark the particular passages complained of. ${ }^{40}$ The jury is given the book to read, sometimes being allowed to take it home and read it, otherwise being given a day or so in court for this purpose.

\section{The Supposed Defense of Publication for the Public Good}

It was Sir James Fitzjames Stephen who first formulated a proposition with regard to this supposed defense in his Digest of the Criminal Law: ${ }^{47}$

A person is justified in exhibiting disgusting objects, or publishing obscene books, papers, writing, prints, pictures, drawings, or other representations, if their exhibition or publication is for the public good, as being necessary or advantageous to religion or morality, to the administration of justice, the pursuit of science, literature, or art, or other objects of general interest; but the justification ceases if the publication is made in such a manner, to such an extent, or under such circumstances, as to exceed what the public good requires in regard to the particular matter published.

This suggested defense was accepted by the learned recorder in Rex v. De Montalk. He directed the jury that "it would be a good defence in this case if the thing was done for the public's good." ${ }^{a}$ The Court of Criminal Appeal, in dismissing the appeal, made no comment on this aspect of the case, and we are left completely in the dark whether it was regarded favorably or otherwise.

The argument that there is a defense of publication for the common good is sometimes advanced in connection with the procedure under the Obscene Publications Act, I857, and supported by reference to the wording of the section, which empowers the magistrates to make an order for destruction only if they are satisfied that publication of the articles would amount to a misdemeanor and would be "proper to be prosecuted as such." Blackburn, J., in Regina $v$. Hicklin, thought that the object of the legislature in inserting this last clause was "to guard against the vexa${ }^{45}$ Q.B.D. 607 (1878).

10 The Law of Libel Amendment Act, I888, 5 I \& 52 VICT., c. $64, \$ 7$, rendcred it unnecessary to include the particulars of the obscene passages in the indictment. See Rex v. Barraclough, [19o6] I K.B. 201 .

47 J. F. Stephen, A Digest of the Criminal Law art. 228, at 172-73 (9th ed., Sturge i950).

67a (1932) 23 Crim. App. R. 182, 183. 
tious prosecution of publishers of old and recognized standard works, in which there may be some obscene or mischievous matter." 48

It has been suggested that there is no reason to give the clause so narrow an interpretation, and that it may refer to the common law defense which Stephen thought existed. ${ }^{49}$ An anonymous writer in the Justice of the Peace and Local Government Review attaches considerable importance to the clause in question, which, he maintains, contains a "let-out" which"

... is used-half unconsciously, it may be-in the ordinary case of an established classic, a serious scientific book, and in most cases of a novel dealing with sexual topics written by an author of admitted standing and published by a known and reputable firm.

It should be observed that Stephen did not suggest that publication for the common good should be an unqualified defense. "The justification ceases," he says, "if the publication is made in such a manner, to such an extent, or under such circumstances, as to exceed what the public good requires in regard to the particular matter published." ${ }^{21}$ This point must have been in the mind of Cockburn, C.J., in Regina v. Hicklin, for he remarked that ${ }^{52}$

... a medical treatise ... may, in a certain sense, be obscene, and yet not the subject for indictment; but it can never be that these prints may be exhibited for anyone, boys and girls, to see as they pass. The immenity must depend upon the circumstances of the publication.

\section{Circumstances of Publication}

That it is relevant to consider the time and place and manner of publication is apparent not only from the foregoing paragraph, but also from the case of Regina $v$. Thomson, ${ }^{53}$ where the Common Serjeant directed the jury that they had to deal with "the time and circumstances under which the book was put forth." It is material, he said, to consider the titles and contents of other books found on the premises. These may be relevant as tending to show that the one in question was sold with a view to corrupt the public morals. In the recent Scottish case of Galletly $v$. Laird $^{54}$ the circumstances of sale were held relevant, and there are other authorities in support of this view. ${ }^{55}$ It is interesting to read Odgers' remark in this connection, that when the net cast by the Act of 1857 catches a book like the Decameron, it is not infrequently because it is being offered in association with other books of a worthless character. ${ }^{58}$

${ }^{48}$ L.R. 3 Q.B. 360,374 (1868).

${ }^{30}$ Stevas, supra note 30 , at 827 .

${ }^{50}$ TI 8 JUst. P. 68r (1954).

${ }^{51}$ STEPHEN, op. cit. supra note 47 , art. 228 , at 173 .

${ }^{52}$ L.R. 3 Q.B. 360,367 (1868).

${ }^{53} 64$ Just. P. 456,457 (1900).

54 [1953] Sess. Cas. 16 (Scot. J.).

5 See McGowan v. Langmuir, (193I) Scots L. T. (pt. 7) 94, (r931) Sess. Cas. ro (Scot. J.); Police v. Fouldes, [1954] CRrM. L. REv. 868; The Times, Oct. 12, 1954, p. 4 (The Stipendiary Magistrate at Lecds).

so Odgers, stpra note 17 , at 614 . 


\section{E. The Standard of Contemporary Literature}

The courts have recently had to consider whether other books which circulate freely at the time of the prosecution may be produced for the jury or magistrates to examine and compare with that which is the subject of the complaint. It has been decided that such evidence is not admissible. In Regina $v$. Reiter, ${ }^{57}$ Lord Goddard, C.J., adopted the words of the Lord Justice-General of Scotland in Galletly v. Laird" to the effect that "the character of other books is a collateral issue, the exploration of which would be endless and futile."

This ruling does not mean that the jury are to ignore current trends in writing and publishing. As Lord Goddard observed: "I can well understand that nowadays novelists and writers discuss things which would not have been discussed in the reign of Queen Victoria." ${ }^{99}$ The fact that the test of obscenity was laid down in 1868 , observed Stable, J., in the Warburg case, "does not mean that you have to consider whether this book is an obscene book by the standards of nearly a century ago." In another passage, the learned judge inquires rhetorically: ${ }^{\mathbf{6 1}}$

Are we to take our literary standards as beings the level of something that is suitable for a fourteen-year-old schoolgirl? Or do we go even further back than that, and are we to be reduced to the sort of books that one reads as a child in the nursery? The answer to that is: Of course not. A mass of literature, great literature, from many angles is wholly unsuitable for reading by the adolescent, but that does not mean that the publisher is guilty of a criminal offence for making those works available to the general public.

The standard to be adopted is that of "the average, decent, well-meaning man or woman,"62 to use the words of Stable, J. This is the standard of l'homme moyen sensuel mentioned by Judge Woolsey in the Ulysses case: $:^{63}$

... a person with average sex instincts ... who plays, in this branch of legal inquiry, the same role of hypothetical reagent as does the "reasonable man" in the law of torts and "the man learned in the art" on questions of invention in patent law.

The question is what would be the effect of the work on such a person. Would it "suggest . . . thoughts of a most impure and libidinous character,"64 or tend to "stir the sex impulses or to lead to sexually impure and lustful thoughts"? ${ }^{65}$ It is not simply a question of the effect on the young or the weak, though they must be borne in mind. Nor is it whether bishops or respectable people who have got clean minds would be corrupted. ${ }^{60}$ In fact, in the last analysis, the matter rests with the jury or

${ }^{67}$ [1954] 2 Weekly L. R. 638, 641 .

${ }^{68}$ [1953] Sess. Cas. 16, 27 (Scot. J.).

[0 [1954] 2 Weekly L. R. 638, 639-40.

${ }^{\text {co }}$ [1954] I Weekly L. R. I138, Ir39.

01 Id. at I $139-40$.

${ }^{02}$ Id. at II $4 \mathrm{I}$.

${ }^{\circ 3}$ United States v. One Book Called "Ulysses," 5 F. Supp. I82, I84 (S.D.N.Y. I933), aff'd, 72 F.2d 705 (2d Cir. 1934).

of Regina v. Hicklin, L.R. 3 Q.B. 360, 371 (1868) (per Cockburn, C. J.).

" 5 United States v. One Book Called "Ulysses," 5 F. Supp. 182, I85 (1934) (per Woolsey, J.).

${ }^{60}$ Rex v. De Montalk, (1932) 23 Crim. App. R. 182, 183 (summing up of the Recorder of London). 
magistrate-"l'homme moyen sensuel, in the shape of a jury or a magistrate, must decide. ..."67 Perhaps it is as true of the English courts as it is of the American courts to say, as was said recently, that ${ }^{68}$

... [n]ow most courts at least start from the premise that the normal or average person in the community is the proper touchstone, though some still speak of the young and weak as part of the reading public.

\section{III}

\section{The Operation of the Preventive Legislation}

\section{A. Procedure under the Obscene Publications Act, 1857}

It has recently been pointed out that proceedings under Lord Campbell's Act differ from any other class of proceeding that comes before justices "because, although justices make an order for destruction ... no offence is created by this Act." It was intended "not as an instrument of punishment but as preventive legislation. It was meant to give the authorities the power of seizing obscene publications before they were distributed." In the case from which these quotations are taken, ${ }^{60}$ Lord Goddard expressed the opinion that the Act "contains its own procedure: it is a complete code in itself." subject to the usual time limits applying to other proceedings before magistrates. ${ }^{71}$

Before making a destruction order, the justices have to be satisfied that the books are obscene. It has been held that the only way they can arrive at this conclusion is by reading the books and looking at them. It does not require evidence, and there is no need for the prosecution to make out a prima facie case for destruction by indicating the nature of the objection and, where an innuendo is relied on, the nature thereof. The act throws the onus on the occupier of the premises where the obscene literature was found to show cause why those articles which are before the court should not be destroyed. ${ }^{72}$ In another case, it was said that "the book or picture itself provides the best evidence of its own indecency or obscenity or of the absence of such qualities," and that the magistrate must reach a conclusion by examining the article itself: ${ }^{73}$

The character of the offending books or pictures should be ascertained by the only method by which such a fact can be ascertained, viz. by reading the books or looking at the pictures.

${ }^{a 7}$ II 8 JUST. P. 725 (I954).

${ }^{o s}$ Lockhart and McClure, Literature, the Laty of Obscenity, and the Constitution, 38 MINN. L. REv. 295,340 (1954).

${ }^{00}$ Cox v. Stinton, [1951] 2 K.B. I02I, I025.

${ }^{70} \mathrm{Ibid}$.

${ }^{71}$ Summary Jurisdiction Act, 1848 , II \& 12 VICT., c. 43, \$1 1, now replaced by Magistrates' Courts Act, I952, 15 \& 16 GEo. 6 \& 1 ELIz. 2, c. 55, which provides that in the absence of express statutory provision, a time limit of six months applics to the commencement of summary proceedings.

72 Thomson v. Chain Libraries Ltd., [1954] \& Weekly L. R. 999.

${ }^{73}$ Regina v. Reiter, [1954] 2 Weekly L. R. 638, Lord Goddard, C. J., quoting the Lord JusticeGeneral of Scotland, in Galletly v. Laird, [1953] Sess. Cas. I6 (Scot. J.). 
Unfortunately, this means that there is no really uniform standard. This fact was recognized by the Lord Justice-General in Galletly v. Laird, and he said he was "not dismayed by the idea that the opinion of the magistrate . . . is virtually determinative of the question." ${ }^{24}$ It would probably be impossible to abolish this procedure or alter it substantially, but there is need for minor improvements. More uniformity might be secured if a filter were introduced at a preliminary stage in the proceedings by requiring the Director of Public Prosecutions to be notified. This is already the case in prosecutions for obscene libel, for the Prosecution of Offences Regulations, I946, provide that a chief officer of police shall, as respects offenses alleged to have been committed in his district, report to the Director of Public Prosecutions all cases of obscene or indecent libels, exhibitions, or publications in which it appears to him that there is a prima facie case for prosecution. ${ }^{75}$ Whether these arrangements could be extended to cover proceedings under the 1857 Act is a matter for consideration.

Two shortcomings of the procedure under this act are frequently criticized. Firstly, the only person at present entitled to be summoned to show cause why there should not be an order for destruction of the articles seized is the occupier of the premises where they are found. The author and publishers may be unaware of the proceedings, and they may find their book has been condemned without their having had an opportunity to be heard. Even if they are aware of the proceedings, they have no legal right to intervene, and it is only by the grace of the court that they are heard. Secondly, there is no right to call expert evidence concerning the literary or other value of the work from those qualified to speak on these matters. There is much force in both criticisms, but, as Odgers says, ${ }^{78}$

... against them must be set the purpose of the legislation-which is to give a power to destroy obscene matter before it can do harm, a power to be exercised locally and speedily, a power more akin to the removal of rubbish or refuse from the streets than to the ordinary criminal prosecution.

\section{B. Procedure under the Other Relevant Legislation}

Prosecutions under the Post Office Act for "sending or attempting to send or procure to be sent" postal packets bearing or containing some obscenity ${ }^{77}$ are rare, and when they do arise, they present no problems. Customs seizures are more important, but now that the somewhat involved procedural provisions of the Customs Consolidation Act, $1876,{ }^{78}$ are replaced by schedule 7 of the Customs and Excise Act, $1952,{ }^{79}$ there are few blemishes in the law. It might be an improvement if the author and publisher could be notified of seizures, as well as the owner

7 [1953] Sess. Cas. 16 (Scot. J.).

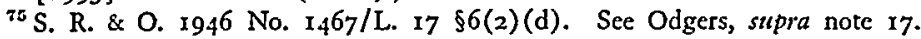

${ }^{70} I d$. at 614 .

${ }^{77}$ See notes 20-22 supra and accompanying text.

${ }^{78} 39$ \& 40 VICT., c. 36 .

${ }^{70}$ Sce note 23 supra and accompanying text. 
of the consignment. Also, perhaps the Director of Public Prosecutions could be informed. ${ }^{80}$

\section{IV}

The Recent Cases and Controversy, the "Horror Comics" Act, and the Proposed Obscene Publications Bill

\section{A. The Recent Cases and Controversy}

At the beginning of this article, reference was made to the fact that there has recently been a new wave of prosecutions for obscene libel and proceedings under the Act of 1857 . During the last few years, there occurred several cases which were reported as containing material of interest to the lawyer ${ }^{81}$ and several which were not reported, save in the daily press, ${ }^{82}$ but which were of great interest to authors and publishers. These cases gave rise to two outbursts of correspondence in The Times, ${ }^{83}$ one adjournment debate, ${ }^{84}$ several articles in popular and legal journals, ${ }^{85}$ and some broadcast talks. ${ }^{86}$

But the most significant development was that the Secretary-General of the Society of Authors called together a strong committee in November I954 to consider the existing law and to recommend reforms. The membership of the committee, which was originally presided over by Sir Alan (A.P.) Herbert, and subsequently by Sir Gerald Barry, included publishers, authors, critics, journalists, a Member of Parliament, and some printers and lawyers. This committee was entirely unofficial, although the Home Secretary expressed great interest in its work and promised to give close attention to any representations which the committee might make. At the end of 1954 , three documents were submitted to the Home Office: an historical survey of the law and its workings from the earliest times, a memorandum on the present state of the law, and a fully drafted bill. ${ }^{87}$ The latter was made public on February 3, I955, and the proposals received widespread support,

${ }^{80}$ These suggestions are elaborated in 118 Jusr. P. 817 (1954).

${ }^{81}$ See Cox v. Stinton, [195I] 2 K.B. 102I; Paget Publications, Ltd. v. Watson, [1952] I All E.R. 1256; Galletly v. Laird, [1953] Sess. Cas. 16 (Scot, J.); Thomson v. Chain Libraries Ltd., [1954] X Weekly L. R. 999; Regina v. Martin Secker \& Warburg, Ltd., [1954] I Weekly L. R. I138; Regina v. Reiter, [1954] 2 Weekly L. R. 638.

${ }^{82}$ Prosccutions of such reputable publishers as Hutchinson \& Co. (Publishers), Ltd,, and William Heinemann, Ltd., caused great concern. Sce accounts of these two cases in The Times, July 27, 1954, p. 4; Sept. 18, 1954, p. 3; Oct. 19, 1954, p. 4; Nov. 30, 1954, p. 3; and Dec. 1, 1954, p. 5. In the Heinemann case, two juries failed to agrce, and the third trial resulted in a formal acquittal, no evidence being offered by the prosecution. See also Police v. Fouldes, [1954] CRIM. L. REv. 868, wherc the order of the Swindon magistrates that an edition of the Decameron be destroyed was reversed on appeal. Other cases were Regina v. Self, The Times, July 29, 1954, p. 4; and Regina v. Kaye, The Times, Sept. 25 , 1954, p. 3 .

${ }^{83}$ Correspondence in The Times commencing June 5, 1954 and Oct. 27, 1954.

${ }^{86} 533$ H. C. Deb. (5th ser.) ror2-20 (1954).

${ }^{85}$ E.g., Stevas, supra notes 30 and 31 ; Lewis An Afterthought On Obscenity. The Spectator, Jan, 21, I955; and 118 Just. P. 664, 680, 694, 709, 725, 812 (1954). The latter articles have becn reprinted in pamphlet form, entitled Obscene Publications (1954).

${ }^{80}$ Odgers, The Law and Obscenity, 52 The Listener 557, 613 (1954).

${ }^{87}$ See Stevas, Obscenity and Law Reform. The Spectator, Feb. 4, 1955. 
including a leading article in The Times calling for the introdution of legislation on the lines proposed by the Committee.

At the same time, the Home Office was considering the problem of the sale of horror comics, which was giving rise to concern. It was hoped that a measure would be introduced dealing jointly with the two matters, but these hopes were shattered when a measure, limited in scope to the horror comics question, was introduced by the Home Secretary, on February I0, 1955. The Second Reading debate on this bill, the Children and Young Persons (Harmful Publications) Bill, ${ }^{88}$ took place on February 22, $1955,{ }^{89}$ when the measure was severely attacked by several members, principally on the ground that it sought to embody the Hicklin test for the first time into a statute. The speech of Mr. Roy Jenkins, who had served on the Herbert Committee, was particularly devastating in its attack upon the piece-meal approach to this problem. ${ }^{90}$ The bill was amended and considerably improved in committee, but its main features remained unaltered, and it passed into law on May 6 and

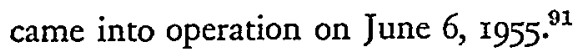

\section{B. The "Horror Comics" Act}

This act applies to any book, magazine, or other like work which is of a kind likely to fall into the hands of children and consists wholly or mainly of stories told in pictures (with or without the addition of written matter), being stories portraying-

(a) the commission of crimes; or

(b) acts of violence or cruelty; or

(c) incidents of a repulsive or horrible nature;

in such a way that the work as a whole would tend to corrupt a child or young person into whose hands it might fall. (\$I).

Section 2 makes it an offense to print, publish, sell, or let on hire a work to which this act applies, which is punishable on summary conviction with imprisonment for not more than four months or a fine not exceeding $f_{100}$ or both. It is provided by section 2(2) that no prosecution is to be instituted except by, or with the consent of, the Attorney-General. Where proceedings are commenced against someone under section 2, power of search and seizure is provided by section 3 upon a warrant issued by a justice of the peace. The court may order articles seized to be forfeited upon conviction of the person responsible for them of an offense under section 2. The importation of any work to which this act applies is prohibited by section 4 . Because of the extensive criticism which this measure encountered, and in order to facilitate its passage through all the necessary stages during the lifetime of the late Parliament, a clause was inserted in section 5 giving to the act a limited life of ten years, so that it will expire on December $3^{\mathrm{I}}$, 1965 "unless Parliament otherwise determines."

${ }^{88}$ Bill 43 (Feb. Io, 1955).

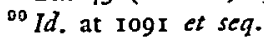

${ }^{80} 537$ H. C. Dr.s. (5th ser.) I074 et seq. (1955).

92 3 \& 4 Eliz. 2, c. 28 (1955). 
C. The Obscene Publications Bill

On March 15, 1955, Mr. Roy Jenkins, M.P., obtained leave to introduce a bill to amend and consolidate the law relating to obscene publications, under what is known as the Ten-Minute Rule.92 Under this procedure, only one speech is allowed in support of the measure, of ten-minute duration, and then the matter is put to the vote. It was agreed that the bill should be printed, but owing to the pressure on parliamentary time, it got no further than this stage and lapsed with the prorogation and dissolution of Parliament in May 1955, prior to the general election. The bill is, however, on record as a parliamentary document, ${ }^{03}$ and no doubt an effort will be made to reintroduce it in the new Parliament.

The bill proposes the abolition of the common law misdemeanor of obscene libel and the substitution of a new statutory offense in its place which would be committed by any person "who shall distribute, circulate, sell or offer for sale, or write, draw, print or manufacture for any of the aforesaid purposes, any obscene matter." $(\S I)$. It is further provided, in this section, that no person is to be convicted of this offense

... unless it is established by the prosecution either

(a) that the accused intended to corrupt the persons to or among whom the said matter was intended or was likely to be so distributed, circulated, sold, or offered for sale; or

(b) that in so distributing, circulating, selling, or offering for sale, or writing, drawing, printing or manufacturing for any of the aforesaid purposes, he was reckless as to whether the said matter would or would not have a corrupting effect upon such persons.

"Reckless" is defined for the purpose of the bill to mean "advertence in the mind of the accused person as to the corrupting consequences of his action, although there is no desire that such consequences shall take place."

It will be seen that the bill clearly recognizes the double aspect of mens rea and does not simply "introduce intention" into the law of obscene publications. This is a welcome advance in the thinking of the would-be reformers. The definition of "reckless" is not altogether satisfactory, however-should it not be defined as advertence to the possibility of corrupting consequences?

Section 2 seeks to state the considerations which a court must bear in mind in deciding whether any matter is obscene. Four considerations are listed, which may be summarized thus:

(a) the general character and dominant effect of the work;

(b) the literary or artistic merit of the work, or its medical, legal, political, religious, or scientific character or importance;

(c) the persons among whom the matter was distributed or was intended or likely to be distributed;

(d) evidence, if any, that the matter actually had a corrupting effect.

${ }^{82} 538$ H. C. Deb. (5th ser.) I133 et seq. (1955).

${ }^{03}$ Bill 56 (March 15, 1955). 
In connection with (b), expert opinion is declared to be admissible, and a proviso to section I says that on the question whether the work is obscene, the author and publisher shall be entitled to be heard.

Section 3 provides that in deciding the question of intent or recklessness the court shall have regard to:

(a) the general character of the person charged, and where relevant, the nature of his business;

(b) the general character and dominant effect of the matter alleged to be obscene;

(c) any evidence concerning the accused's intention in distributing the work.

There is much that is valuable in these proposals. The influence of Judge Augustus Hand's judgment in the Ulysses case ${ }^{94}$ is readily perceived in the references to the "dominant effect" of the work and the provision for the evidence of literary critics to be admissible. It may be considered that the circumstances of publication are already regarded as relevant, and so, one might well argue, is the general character of the work. There is little that is revolutionary save the admission of the evidence of experts. But one part of section 3 seems rather extraordinary-i.e., 3(a), which seeks to require the court to have reference to "the general character of the person charged, and where relevant, the nature of his business" in deciding the question of mens rea. It is difficult to see how the court can be allowed to hear evidence concerning the character of the accused unless the defense puts the character in issue or tenders the evidence, and if the proposal is not concerned with evidence and amounts to no more than a general direction to the court, it seems to have little value.

The bill seeks to widen the scope of "obscenity" to include the undue exploitation of horror, cruelty, or violence in a publication, whether pictorially or otherwise. $(\$ 4)$. The aim here was to embrace the "horror comic," now separately provided for by the Act of 1955 .

The penalties provided by section 5 for offenses under the act are fines not exceeding $f_{0} 100$ or imprisonment for not more than four months or both. Only summary trial is expressly mentioned, but as the offense is punishable with more than three months' imprisonment, there is an option to the accused to claim trial by jury.

The bill endeavors to consolidate the whole of the law relating to obscene publications, and in this respect, it follows the recommendations of the Joint Committee of both Houses of Parliament in $1908 .^{95}$ Section 7 incorporates the offenses relating to postal packets, and section 9 deals with the customs aspect of obscenity ${ }^{96}$

\footnotetext{
o4 United States v. One Book Called "Ulysses," 72 F.2d 705 (2d Cir. 1934).

${ }^{\circ 5}$ Report from the loint Select Committee on Lotterics and Indecent Advertisements, H. C. 275 of Igo8, p. viii.

"To The bill also proposes to abolish the provisions of the Vagrancy Act, 1824,5 GEo. 4, c. $83, \$ 4$; and the Town Police Clauses Act, $\mathrm{x} 847$, ro \& II VICT., c. $89, \$ 28$, in so far as they relate to obscenity, and to repeal the Indccent Advcrtisements Act, I889, 52 \& 53 VICT., c. I 8.
} 
Perhaps the most important part of the bill is section 8 , which deals with the law relating to "destruction orders." The bill repeals Lord Campbell's Act of $1^{857}$ and substitutes a new provision entitling a magistrate to issue a warrant for the police to search and seize, if it appears to him, upon information supplied on oath, that obscene matter is kept in premises within his jurisdiction for the purposes of sale or distribution, etc., and it appears to him that the said sale, distribution, etc. "would have a corrupting effect on persons into whose hands the said matter was likely or was intended to fall." One may perhaps be pardoned for seeing the ghost of Cockburn, C.J., in these words, despite the assertion of Mr. Stevas that "the old Hicklin test is ... abolished." $" 97$

It is further provided that the magistrate shall forthwith notify the AttorneyGeneral and also the persons who appear to be the author, publisher, and printer: and no further proceedings may be taken unless the Attorney-General consents. This would ensure more uniformity of treatment throughout the country.

The second stage of the procedure commences with the issuing of a summons to the occupier to appear and show cause why the matter seized should not be destroyed. This follows closely the procedure under the 1857 Act. The big difference is that the author, publisher, printer, or distributor are given a locus standi in the second stage of the proceedings-i.e., a right to appear and call evidence. $(\$ 8(4))$. More debatable is the provision that it shall be the duty of the prosecutor to indicate to the court wherein lies the alleged obscenity of the matter under consideration. Although it is generally the practice for the police to indicate the nature of their objections, at present, they are not obliged to do so; and, as we have seen, ${ }^{98}$ it is for the magistrates, by reading the book or inspecting the article in question, to decide for themselves whether it is obscene.

In conclusion, it may be said that the bill has served a useful purpose in bringing out some of the weaknesses of the present law. While there may be much to be said for revising the procedure under the Act of 1857 , it seems less certain that the sweeping changes proposed in relation to the misdemeanor of obscene libel are necessary, and it is by no means inconceivable that the courts may gradually come to accept changes in their approach to some of the matters provided for by the bille.g., proof of mens rea and the test of obscenity. Indeed, a case could be made out to the effect that most of these suggestions have already been accepted as representing the law by more enlightened courts-e.g., dominant effect, intent and recklessness, and relevancy of circumstances of publication. The reformers wish to create uniformity of enlightenment, however.

We shall end this article, as we began, by quoting from the excellent direction of Stable, J., in the Warburg case: $:^{99}$

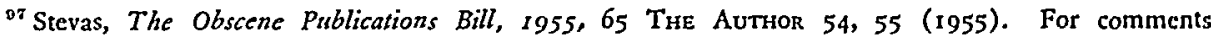
on the original draft bill, see Eddy, Obscene Publications: Society of Authors' Draft Bill, [1955] Crim. L. REv. 218; Hollis, Obscenity and the Law, The Tablet, Feb. 12, 1955, p. 149.

${ }^{98} \mathrm{Sec}$ notes 72-74 stipra and accompanying text.

${ }^{90}$ [1954] I Weekly L. R. I138, 1143 .
} 
... in our desire for a healthy society, if we drive the criminal law too far, further than it ought to go, is there not a risk that there will be a revolt, a demand for a change in the law, and that the pendulum may swing too far the other way and allow to creep in things that at the moment we can exclude and keep out?

The tendency to drive the criminal law too far has produced a demand for a change in the law, but it is incumbent on those who advocate reforms to take very great care lest the measures they propose produce a reaction in those quarters best situated to wreck their endeavors. At the same time, the judges and magistrates would do well to study these proposals and see whether some of the defects which they are designed to rectify cannot be remedied without waiting for Parliament to act. 